\title{
Evaluation of the radioactive impact of the phosphogypsum wastes used as amendment in agriculture soils
}

\author{
R. El Mrabet' ${ }^{1}$ J .M. Abril ${ }^{2}$, A. Delgado 3 , R.G. Tenorio ${ }^{4}$, G. Manjón ${ }^{4}$ \\ and R. Periáñez ${ }^{2}$ \\ ${ }^{1}$ Centre National de l'Énergie des Sciences et des Techniques Nucléaires (CNESTEN), \\ BP. 1382, Rabat, RP 10001, Maroc, e-mail: r.elmrabet@cnesten.org.ma \\ ${ }^{2}$ Dpto. Física Aplicada I, EUITA, University of Seville, Carretera de Utrera km 1, \\ 41013 Seville, Spain \\ ${ }^{3}$ Dpto. Ciencias Agroforestales, EUITA, University of Seville, Carretera de Utrera km 1, \\ 41013 Seville, Spain \\ ${ }^{4}$ Dpto. Física Aplicada II, ETSA, University of Seville, Avda. Reina Mercedes s/n, \\ 41012 Seville, Spain
}

\begin{abstract}
Some $3 \times 10^{9} \mathrm{~kg}$ of phosphogypsum (PG) wastes are annually generated by two fertiliser-production factories in Huelva (south-western Spain). PG has relatively high concentrations of ${ }^{226} \mathrm{Ra}$ and other radionuclides, with an special concern due to the ${ }^{222} \mathrm{Rn}$ emissions. These wastes could be used to improve the fertility of agriculture soils in a large former marsh area of the Guadalquivir river. Thus, it is interesting to study the levels and behaviour of natural radionuclides within this system to evaluate the radioactive impact of this amendment. An agronomical test is being conducted by one of the authors in an experimental farm in Lebrija (Seville). The soils are treated with 13 and $26 \mathrm{t} \mathrm{ha}^{-1}$ of PG, $30 \mathrm{t} \mathrm{ha}^{-1}$ of manure. Each treatment was repeated twice and continued for two years with beetroot and cotton plant production. We are measuring ${ }^{226} \mathrm{Ra}$ (by alpha counting and gamma spectrometry) and $\mathrm{U}$ isotopes (by alpha spectrometry and ICP-MS analysis) in drainage waters, soils and vegetal-tissues samples. The PG used in the treatment has $620 \pm 70 \mathrm{~Bq} \mathrm{~kg}^{-1}$ of ${ }^{226} \mathrm{Ra}$. The drainage waters have ${ }^{226} \mathrm{Ra}$ contents similar to those from non-contaminated natural waters, but the uranium concentrations are one order of magnitude higher. Our results are suggesting that the major uranium input comes from the application of phosphatefertiliser. No significant levels of radionuclides were found in the vegetal tissues.
\end{abstract}

\section{INTRODUCTION}

A large marsh area of the Guadalquivir River was reclaimed for agriculture uses in the XXth century. These soils have high contents of salts and sodium, and require special irrigation and drainage. The farmers routinely have to apply some amendments to the soils to maintain their fertility. The PG could be used for this purpose. It is improving the texture of the soil and represent and additional supply of bio-available phosphorus.

PG is the main waste of phosphoric acid factories, which use phosphate rock as raw material. It is known (Bolívar et al., 1996) that activity concentrations of ${ }^{238} \mathrm{U}$ in phosphate rocks are high. Indeed, depending on their origin (Morocco, Senegal or Togo), ${ }^{238} \mathrm{U}$ activity concentrations range from 700 upto $1000 \mathrm{~Bq} \mathrm{~kg}^{-1}$. Ra-isotopes, essentially ${ }^{226} \mathrm{Ra}$, are also present in phosphate rock, being the activity concentrations range $1000-1300 \mathrm{~Bq} \mathrm{~kg}{ }^{-1}$. Some $85 \%$ of phosphate rock uranium follows the phosphoric acid, while about $90 \%$ of the ${ }^{226}$ Ra remains in the PG wastes (Bolivar et al., 1996). 
Some $2 \times 10^{9} \mathrm{~kg}$ of phosphate rocks are annually treated by two phosphoric acid factories in Huelva (south-western Spain), producing some $3 \times 10^{9} \mathrm{~kg}$ of PG. Wastes are stored in large PG piles lying in the right bank of the Tinto River, close to the city of Huelva. The activity concentrations of natural radionuclides in PG are about 50 times higher than the ones in typical soils; and contribute to a local enhancement of the ${ }^{222} \mathrm{Rn}$ concentration in air in the nearest inhabited area. For this reason, there is a public concern about the safety of these disposals and about the need of restoring this natural environment.

Using the PG as an amendment in agriculture soils, the concentrations of radionuclides can be diluted till reach the usual environmental levels. Thus, this practice could provide a satisfactory pathway of elimination of these wastes with a remarkable additional value for the farmers.

To prevent unacceptable risks, the commercial use of PG in agriculture is permitted in the USA if the certified average ${ }^{226} \mathrm{Ra}$ concentration does not exceed $370 \mathrm{~Bq} \mathrm{~kg}^{-1}$ (USEPA, 1992). However, Cancio et al. (1993) have reported concentrations of ${ }^{226} \mathrm{Ra}$ in PG from Huelva, ranging from 400 up to $1000 \mathrm{~Bq} \mathrm{~kg}^{-1}$. Moreno et al. (2000) have studied the dissolution of PG by water. The ${ }^{226} \mathrm{Ra}$ activity concentration dissolved ranged $300-600 \mathrm{~Bq} \mathrm{~kg}$-1 of PG and the activity concentration in the insoluble fraction was $140-573 \mathrm{~Bq} \mathrm{~kg}{ }^{-1}$ of PG. Furthermore, Bolivar et al. (1996) have measured ${ }^{210} \mathrm{Po}$ and ${ }^{238} \mathrm{U}$ in this PG, being concentrations about $530-780 \mathrm{~Bq} \mathrm{~kg}$ of ${ }^{210} \mathrm{Po}$ and $16-225 \mathrm{~Bq} \mathrm{~kg}^{-1}$ of ${ }^{238} \mathrm{U}$. Then, it is advisable to study the levels and behaviour of these radionuclides in these particular agricultural soils and vegetable tissues in order to ensure the radiological safety of this practice. Similar studies have been conducted in several Florida soils (see Alcordo et al., 1999 and the references within it), but there is a lack of knowledge about the effects of PG in our studied environment.

\section{MATERIALS AND METHODS}

The experimental farm is placed in the sector B-XII of the marsh zone of Guadalquivir river, close to the town of Lebrija (Sevilla, Spain). It is rectangular and flat, with an extension of 4 ha and an averaged elevation of $3 \mathrm{~m}$ above the sea level. This surface has been divided into 8 regular and rectangular strips of 250x20 $\mathrm{m}^{2}$ longitudinally crossed by three drainage pipe-lines (see Fig.1). The drainage waters are conducted, through a small canal, towards the Guadalquivir river. The different strips are treated with PG (13 and $\left.26 \mathrm{t} \mathrm{ha}^{-1}\right)$, manure $\left(30 \mathrm{t} \mathrm{ha}^{-1}\right)$, and a control test. Each treatment was repeated in a second strip and continued for two years. The farm was cultivated with beetroot and cotton plant (50\% each) in rotation. A full agronomical study has been conducted during 3 years, starting in 1998. The rain and irrigation episodes were registered, and regular sampling campaigns followed most of them. Some $50 \mathrm{~mL}$ were collected at regular times intervals from each drainage pipe-line, and then used for $\mathrm{N}$ and $\mathrm{P}$ analysis. These samples, stored in a fridge at $4^{\circ} \mathrm{C}$ were then accumulated and acidified with $\mathrm{HNO}_{3}$ (to prevent adsorption onto the container walls) for radioisotopes determination. We accumulated all the samples from the two strips with the same treatment in order to get water volumes of the order of $1 \mathrm{~L}$.

The hydrological balance during the campaigns 1998/99 and 1999/2000 was determined, being the total input of water (rain plus irrigation) about $1000 \mathrm{~mm}$. The surface runoff was negligible and most of the water disappeared by plant transpiration and soil reservoir.

Soils were sampled for standard analysis. Three points were selected along each one of the 8 strips (at the centre and at $50 \mathrm{~m}$ towards the edges in a longitudinal section), and at each site samples were collected from three different depths $(30 \mathrm{~cm}, 60 \mathrm{~cm}$ and $90 \mathrm{~cm})$. The samples collected at the centre of each strip have been measured by gamma spectrometry to find out concentrations of ${ }^{226} \mathrm{Ra}$, ${ }^{234} \mathrm{Th},{ }^{137} \mathrm{Cs},{ }^{228} \mathrm{Ac}$ and ${ }^{40} \mathrm{~K}$, and they are compared against an undisturbed marsh soil sample.

Vegetal tissues are available for cotton plants, sampled from the different strips. They are plant leaves from de bottom part (old tissues) and have been measured by gamma spectrometry.

A sample of the phosphogypsum used for the amendment has been measured by gamma spectrometry, as well as two samples of phosphate fertilisers. Some additional measurements of ${ }^{238} \mathrm{U}$ were carried out by ICP-MS in the Central Laboratories of the Huelva University and in the THERMO-Element facilities. 
For gamma spectrometry we used high efficiency ReGe and XTRA detectors and the Genie software. The standard geometry for measurements consisted in 50 grams of pounded soils prepared in a petri box. To measure the ${ }^{226} \mathrm{Ra}$ through its $186 \mathrm{keV}$ emission it is necessary to solve the interference due to the $185.7 \mathrm{keV}$ emission from the ${ }^{235} \mathrm{U}$. In PG and fertilisers samples it was possible to find out the ${ }^{235} \mathrm{U}$ activity through its $143.8 \mathrm{keV}$ emission, but for soil samples it was under our detection limit. Then its concentration was estimated through the measured ${ }^{234} \mathrm{Th}$ activity (using its $63.3 \mathrm{keV}$ emission) assuming secular equilibrium with its parent $\left({ }^{238} \mathrm{U}\right)$ and the isotopic ratio ${ }^{235} \mathrm{U} /{ }^{238} \mathrm{U}$ (see Laissaoui and Abril, 1999). Alternatively the ${ }^{226} \mathrm{Ra}$ activity can be measured through the ${ }^{214} \mathrm{~Pb}$, one of its decay products, after achieving secular equilibrium (in encapsulated samples to prevent losses of ${ }^{222} \mathrm{Rn}$ ), but the first method is faster and appropriate enough for our present purposes.

${ }^{226} \mathrm{Ra}$ specific activities in water samples were determined using a LB770 low background previously calibrated for total efficiency versus precipitate mass thickness. These procedures have been widely validated and applied. Details can be seen, for instance, in from Morón et al. (1986) and Periáñez and García-León (1993).

The concentrations of U-isotopes in water samples were determined by alpha-spectrometry. A radiochemical method based on a sequential solvent extraction with TBP (Bolivar et al., 1996) was used to isolate uranium from the water samples.

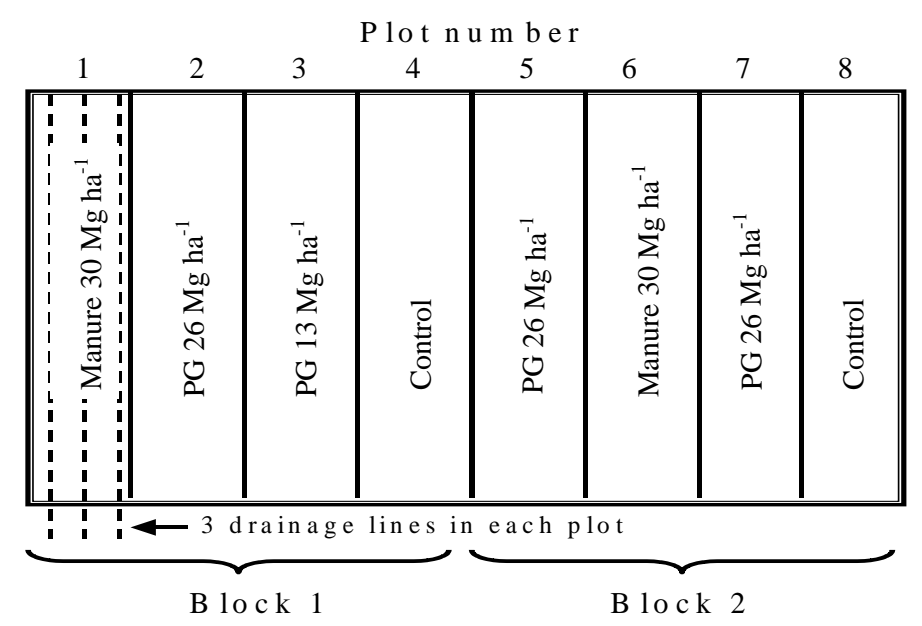

Figure 1.

\section{RESULTS AND DISCUSSION}

${ }^{137} \mathrm{Cs}$ is a man-made radionuclide present in the environment after the atmospheric nuclear weapon tests with a maximum fallout rate in the early sixties. According with its origin, this isotope does not appears in the deeper layers of the undisturbed marsh soil. In the agriculture soils concentrations are lower probably due to the cultural practices (soil removal and irrigation) and reach deeper horizons. Concentration values are in the range of those found by Bolivar et al. (1996) in the area of Huelva (a nearby city).

${ }^{40} \mathrm{~K}$ is a natural singly occurring radionuclide. Their concentrations in soils are comparable with those found by Bolívar et al. (1996) in marsh and soil samples from Huelva , and do not show depth dependence. This is the only radionuclide detected in the vegetal tissues with a mean concentration factor of $0.87 \pm 0.03$.

${ }^{228} \mathrm{Ac}$ is a natural occurring radionuclide from the decay series of the ${ }^{232} \mathrm{Th}$. It is present in small concentrations in the PG and in the phosphate fertilisers. Thus, it can be considered as a reference radionuclide. The concentrations are similar and no depth dependent in the agriculture soils, while its concentration is higher in the top layers of the undisturbed marsh soils. 
${ }^{234}$ Th comes from the radioactive decay of ${ }^{238} \mathrm{U}$. It has a half-live of 24.1 days and different solubility than its parent. When the rate of removal by water is not significant, it is expected to find it in secular equilibrium with its parent. It is present in relatively high concentrations in the two phosphate fertilisers while concentrations in all the soils are similar (with a mean value of $36 \pm 8 \mathrm{~Bq} \mathrm{~kg}$ ). ${ }^{235} \mathrm{U}$ is the head of a natural radioactive decay series. It could be directly measured through its $143.8 \mathrm{keV}$ gamma emission in the PG and fertiliser samples.

The PG used in the treatment has $620 \pm 70 \mathrm{~Bq} / \mathrm{Kg}$ of ${ }^{226} \mathrm{Ra}$. This value is in good agreement with the previous measurements reported by Bolivar et al. (1996) and by Cancio et al. (1993). ${ }^{226} \mathrm{Ra}$ concentration in the $60 \mathrm{~cm}$ horizon of soils in the control strip is similar to those from undisturbed marsh soils, but there is an enhancement of concentrations in the top agriculture soils. Assuming that the $26 \mathrm{t} \mathrm{ha}^{-1}$ of PG are well homogenised over the top $30 \mathrm{~cm}$ of soils, with a mean bulk density of $1300 \mathrm{~kg} \mathrm{~m}^{-3}$, the background ${ }^{226} \mathrm{Ra}$ concentration in soils should be increased about $4 \mathrm{~Bq} \mathrm{~kg}^{-1}$. As most probably this treatment has been apply several times in the past, it could be the reason of the observed enhancement in concentrations.

The main chemical form of Ra in PG is $\mathrm{RaSO}_{4} 2 \mathrm{H}_{2} \mathrm{O}$, which presents a relatively low solubility. On the other hand, GP tends to form large aggregates that offer a low free surface, what prevent the removal of ${ }^{226} \mathrm{Ra}$ by the drainage waters. Indeed, the activity concentrations of ${ }^{226} \mathrm{Ra}$ found in these waters were similar for all the strips and comparable to those from non-contaminated waters. Thus, García-León et a. (1995) reported reference levels under $3 \mathrm{mBq} \mathrm{L}^{-1}$ of ${ }^{226} \mathrm{Ra}$ for natural environments (from a literature review). Nevertheless, Martínez-Aguirre and García-León (1994) measured concentrations ranging $2.4-13.7 \mathrm{mBq} \mathrm{L}^{-1}$ in the Guadalquivir river that increased up to $31 \mathrm{mBq} \mathrm{L}^{-1}$ in its estuary. Consequently,

Table 1. Radionuclide concentrations in phosphogypsum (PG), manure and P fertilisers, determined by $\gamma$ spectrometry $^{\dagger}$.

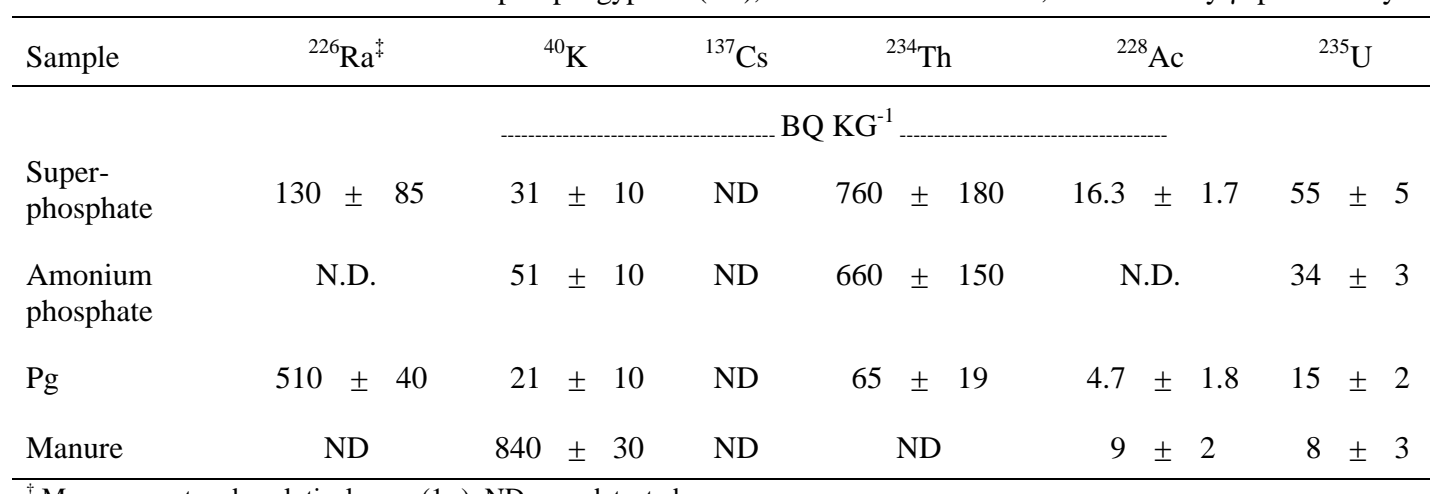

${ }^{\dagger}$ Measurement and analytical error $(1 \sigma)$; ND, non detected

${ }^{\ddagger}$ Corrected through ${ }^{235} \mathrm{U}$ activity concentration.

Table $2 .{ }^{238} \mathrm{U}$ and ${ }^{232} \mathrm{Th}$ activity concentration in P-fertilisers and cotton leaves measured by ICP-MS ${ }^{\dagger}$.

\begin{tabular}{lcc}
\hline \multicolumn{1}{c}{ Sample } & ${ }^{238} \mathrm{U}$ & ${ }^{232} \mathrm{Th}$ \\
\hline Super-phosphate & $-------------\mathrm{Bq} \mathrm{kg}^{-1}$------------- \\
Ammonium-Phosphate & 590 & 846 \\
Leaves (Control) & 496 & 9.0 \\
Leaves (PG 26 $\left.\mathrm{Mg} \mathrm{ha}^{-1}\right)^{\ddagger}$ & $<0.24$ & $\mathrm{ND}^{\S}$ \\
\hline
\end{tabular}

${ }^{\dagger}$ Integration time $0.3 \mathrm{~s} /$ channel $(0.9 \mathrm{~s} / \mathrm{uma})$. Detection limit $0.02 \mathrm{ppm}$. Three measurements for each sample, with $2 \%$ of relative standard deviation.

† PG, phosphogypsum.

$\S$ Non detected. 
Table 3. ${ }^{226}$ Ra activity concentrations of measured by alpha counting in samples of drainage waters from different treatment and dates ${ }^{\dagger}$.

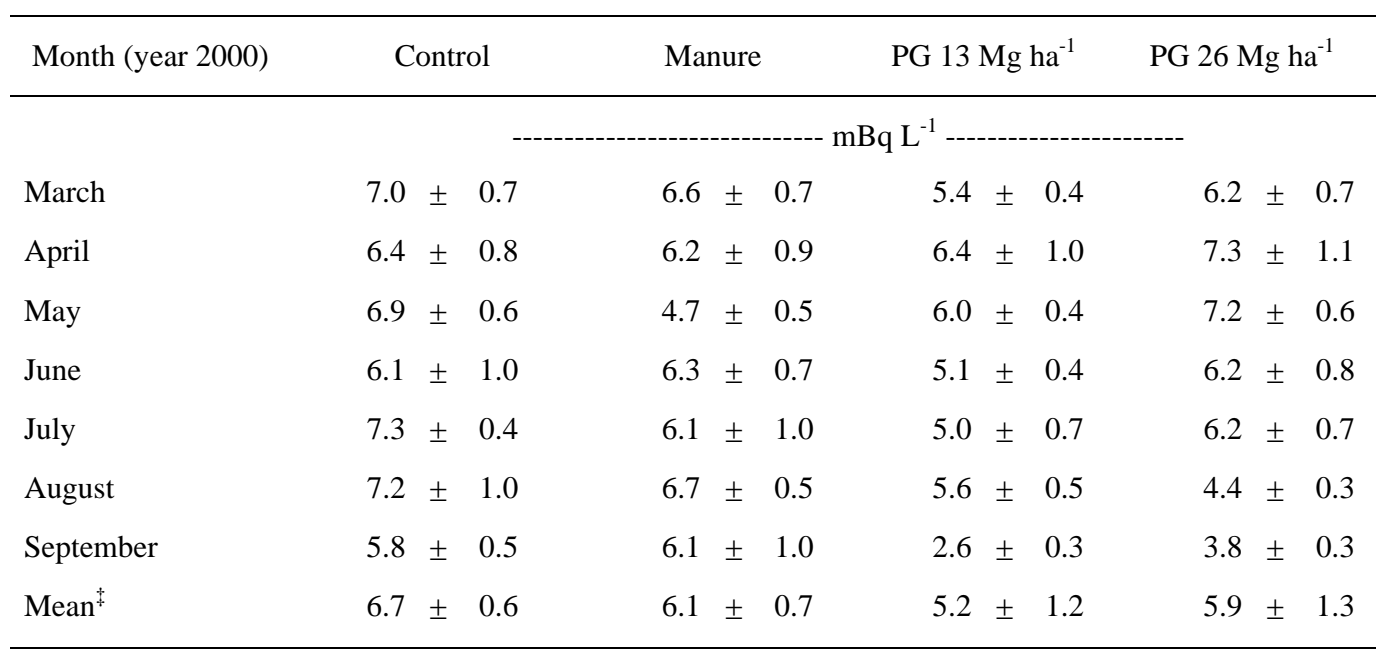

${ }^{\dagger}$ Measurement and analytical error $(1 \sigma)$, samples are accumulated water volumes from the six till drains with the same treatment and for all the drainage episodes during the month; PG, phosphogypsum.

${ }^{\ddagger}$ Mean and standard deviations.

Table 4. Radionuclide concentration in soils after two consecutive treatments (1998 and 1999) and in non reclaimed marsh soil at different depths (gamma spectrometry) ${ }^{\dagger}$.

\begin{tabular}{l} 
r \\
\cline { 3 - 7 }
\end{tabular}


collected in the marsh area of the Huelva estuary, from 18 up to $728 \mathrm{~Bq} \mathrm{~kg}^{-1}$ (Martínez-Aguirre et al., 1997), are lower than the ${ }^{238} \mathrm{U}$ activity concentration measured in PG (Bolívar et al., 1995). Consequently, it is not expected that a phosphogypsum amendment can significantly contribute to increase the activity concentration of ${ }^{238} \mathrm{U}$ in draining waters. Nevertheless, the activity concentrations of uranium isotopes in draining waters were one order of magnitude higher than those reported from uncontaminated waters (García-León et al., 1995), where the typical levels were lower than $25 \mathrm{mBq} \mathrm{L}^{-1}$.

The activity concentrations obtained by alpha-spectrometry were contrasted against measurements made by ICP-MS, which were carried out in the Thermo-Elemental facilities (U.K.) A semi-quantitative analysis of one unfiltered water sample provided values of $\left[{ }^{238} \mathrm{U}\right]=28 \mathrm{ppb}$ $\left(338 \mathrm{mBq} \mathrm{L}^{-1}\right),\left[{ }^{235} \mathrm{U}\right]=0.08 \mathrm{ppb}\left(6.3 \mathrm{mBq} \mathrm{L}^{-1}\right)$ and $\left[{ }^{234} \mathrm{U}\right]=$ N.D, which are consistent with activity concentration determined by alpha-spectrometry.

Summarising the annual fluxes of U-isotopes and ${ }^{226} \mathrm{Ra}$ related to the drainage waters. ${ }^{226}$ Ra fluxes are similar, with also similar activity concentrations and cumulative drainage volumes. The major fluxes of U-isotopes appear with the manure treatment, since it improves the soil texture and enhances the drainage. As the U-isotopes fluxes are significantly different while their concentrations in water are similar, one can conclude the removal of these radionuclides by the drainage waters. The above results are suggesting that the major uranium input may come from the application of phosphate-fertiliser $\left(600 \mathrm{~kg} \mathrm{ha}^{-1}\right.$ for all the strips). Effectively, the activity concentration of ${ }^{238} \mathrm{U}$ and ${ }^{234} \mathrm{U}$ in phosphoric acid $\left(\mathrm{H}_{3} \mathrm{PO}_{4}\right)$ is about $650 \mathrm{~Bq} / \mathrm{kg}$ (Bolívar et. al. 1995).

A typical ${ }^{238} \mathrm{U} /{ }^{234} \mathrm{U}$ activity ratio slightly higher than the unity was observed in the whole of analyses. These results are in agreement with the phosphate rock origin of uranium.

In order to estimate the radiological impact of the current agriculture practices we have to note that from our data no significant levels of radionuclides were found in the vegetal tissues. The cumulative application of PG may increase the ${ }^{226}$ Ra concentration in soils and thus the ${ }^{222} \mathrm{Rn}$ exhalation, although this has not been studied within the present work. The red American crab has prospered in this

Table 5. U-isotopes concentrations and isotopic ratios in drainage waters from different treatments and dates, determined by alpha spectrometry ${ }^{\dagger}$.

\begin{tabular}{|c|c|c|c|c|c|}
\hline Treatment & Date & ${ }^{238} \mathrm{U}$ & ${ }^{235} \mathrm{U}$ & ${ }^{234} U$ & ${ }^{34} U /{ }^{238} U$ \\
\hline & |------- & ---------. & mB & $\begin{array}{l}-1 \\
\end{array}$ & ------ \\
\hline \multirow[t]{4}{*}{ Control } & 12-December, 98 & $188 \pm 5$ & $7.3 \pm 0.6$ & $217 \pm 6$ & $1.15 \pm 0.04$ \\
\hline & 22-January, 99 & $164 \pm 5$ & $5.7 \pm 0.6$ & $198 \pm 6$ & $1.21 \pm 0.05$ \\
\hline & 25-January, 99 & $180 \pm 9$ & $7.0 \pm 1.1$ & $201 \pm 10$ & $1.12 \pm 0.08$ \\
\hline & $\operatorname{Mean}^{\ddagger}$ & $177 \pm 12$ & $6.7 \pm 0.9$ & $205 \pm 10$ & $1.16 \pm 0.10$ \\
\hline Manure $30 \mathrm{Mg} \mathrm{ha}^{-1}$ & 22-January, 99 & $200 \pm 7$ & $6.9 \pm 0.8$ & $229 \pm 8$ & $1.15 \pm 0.06$ \\
\hline \multirow[t]{4}{*}{ PG $13 \mathrm{Mg} \mathrm{ha}^{-1}$} & 12-December, 98 & $196 \pm 10$ & $8.5 \pm 1.2$ & $148 \pm 11$ & $0.76 \pm 0.07$ \\
\hline & 22-January, 99 & $174 \pm 5$ & $7.0 \pm 0.6$ & $198 \pm 5$ & $1.14 \pm 0.04$ \\
\hline & 23-January, 99 & $207 \pm 8$ & $9.6 \pm 1.2$ & $256 \pm 10$ & $1.24 \pm 0.07$ \\
\hline & $\operatorname{Mean}^{\ddagger}$ & $192 \pm 17$ & $8.4 \pm 1.3$ & $201 \pm 54$ & $1.04 \pm 0.30$ \\
\hline \multirow[t]{5}{*}{ PG $26 \mathrm{Mg} \mathrm{ha}^{-1}$} & 12-December, 98 & $175 \pm 5$ & $7.2 \pm 0.5$ & $206 \pm 5$ & $1.18 \pm 0.04$ \\
\hline & 22-January, 99 & $170 \pm 6$ & $7.6 \pm 0.7$ & $198 \pm 6$ & $1.16 \pm 0.05$ \\
\hline & 24-January, 99 & $166 \pm 7$ & $5.2 \pm 0.7$ & $192 \pm 7$ & $1.16 \pm 0.06$ \\
\hline & 25-January, 99 & $204 \pm 9$ & $7.6 \pm 1.0$ & $224 \pm 10$ & $1.10 \pm 0.07$ \\
\hline & $\operatorname{Mean}^{\ddagger}$ & $179 \pm 17$ & $6.9 \pm 1.1$ & $205 \pm 14$ & $1.15 \pm 0.14$ \\
\hline
\end{tabular}

${ }^{\dagger}$ Measurement and analytical error (1б). Samples are accumulated water volumes from the six till drains with the same treatment; PG, phosphogypsum ${ }^{\ddagger}$ Mean and standard deviations for the different dates 
environment, although it inhabits more frequently in the rice fields in the opposite river-bank. In a very conservative dose assessment, we can consider the consumption of this crabs as a critical pathway, with consumption rate, Q, of $20 \mathrm{~kg} \mathrm{y}^{-1}$ (4 times the averaged consumption of molluscs and crustaceans in the Huelva region). The received dose, $\mathrm{E}$ (given in $\mathrm{Sv}^{-1}$ ) will be: $\mathrm{E}=\mathrm{Q} \mathrm{C}_{\mathrm{F}}$

where $\mathrm{C}$ is the concentration $\left(\mathrm{Bq} \mathrm{kg}^{-1}\right)$ in crabs estimated from the mean concentration in water and the recommended concentration factors for molluscs $\left(F_{c}=3.0 \times 10^{-2} \mathrm{~m}^{3} \mathrm{~kg}^{-1}\right.$ for ${ }^{238} \mathrm{U}$ and $\mathrm{F}_{\mathrm{c}}=1.0 \mathrm{~m}^{3} \mathrm{~kg}^{-1}$ for ${ }^{226} \mathrm{Ra}$, from NRPB, 1987 ). $\mathrm{D}_{\mathrm{F}}$ is a factor to convert to doses the internal irradiation by ingestion $\left(\mathrm{D}_{\mathrm{F}}=6.3 \times 10^{-8} \mathrm{~Sv} \mathrm{~Bq}^{-1}\right.$ for ${ }^{238} \mathrm{U}$ and $\mathrm{D}_{\mathrm{F}}=3.0 \times 10^{-7} \mathrm{~Sv} \mathrm{~Bq}^{-1}$ for ${ }^{226} \mathrm{Ra}$ ). Thus, $\mathrm{E}=0.051 \mathrm{mS}$ (including the doses from ${ }^{234} \mathrm{U}$ with the same $\mathrm{F}_{\mathrm{c}}$ and $\mathrm{D}_{\mathrm{F}}$ values than ${ }^{238} \mathrm{U}$ ), which clearly is under the recommended limit.

\section{Acknowledgments}

This work has been partially founded by I+D contract with the Spanish ENRESA.

\section{References}

[1] Bolívar, J.P., R. García-Tenorio \& M. García-León. 1996b. Radioactive impact of some phosphogypsum piles in soils and salt marshes evaluated by $\gamma$-ray spectrometry. Appl. Radiat. Isot. 47: 1069-1075.

[2] Alcordo I.S., J.E. Recheigl, C.E. Roessler \& R.C. Littell. 1999. Radiological impact of phosphogypsum applied to soils under bahiagrass pasture. J. Environ. Qual. 28: 1555-1567. 